\title{
Convergence and Divergence between the Arabic 'Udhrî (Chaste) Love and Platonic Love: A Comparative Study
}

\author{
Ahmed Thnaybat \\ Department of Arabic, College of Art, Tafila Technical University, Jordan \\ Hussein Zeidanin (Corresponding author) \\ Department of English, College of Art, Tafila Technical University, Jordan
}

Received: 19-05-2017

doi:10.7575/aiac.ijclts.v.5n.3p.44
Accepted: 23-06-2017

Published: 31-07-2017

\begin{abstract}
The study explores the Udhrî ghazal as a classical literary phenomenon in the Arabic poetry; and it seeks to correlate it with Plato's theories of love in The Symposium. The issues the study raises are: history of the Udhrî love, factors leading to its emergence, impact of Islam on the Udhrî poets, and stages of the Udhrî narrative based on classical Arabic poetry and prose. The study controverts the claims associating the Udhrî ghazal with Islam due to the profound discrepancies between Islamic teachings and the practices and behaviors of the Udhrî poets. It as well reviews the theories of love Plato introduces in the Symposium for the purpose of estimating their manifestations in classical Arabic prose and impact on the Udhrî ghazal. The beginnings of Udhrî love go back to the pre-Islamic era during which poets, such as Antara Al-Absi, frequently combined the motif of chaste love with other related topics in their poems. Yet, the Udhrî ghazal flourishes in the Umayyad age during which poets tackled Udhrî love as an autonomous motif and subgenre. The study further questions the various possible factors, i.e. political, religious, environmental and social, modernists believe have led to the evolution of the Udhrî ghazal in the Islamic age and the Umayyad age.
\end{abstract}

Keywords: Udhrî love, Platonic love, Islam ,Modernists, Ghazal

\section{Introduction}

The study explores the literary phenomenon of the Udhrî ghazal in classical Arabic literature. Many critics and scholars showed an extensive interest in that phenomenon for its unique aesthetic characteristics. The multiple topics characterizing the pre-Islamic Udhrî poem, which usually starts with a prelude to ruins, gives an account of the poet's howdah (i.e. packsaddle) and hunting trips across the desert and digresses to praise and pride, were reduced into the motif of chaste love in the Udhrî poems of the Umayyad poets. The study finds that though the life experiences of the Udhrî poets in the pre-Islamic and Umayyad ages were similar, they produced Udhrî poetry with different semantic and thematic structures. Adherence to the unity of topic signifies the major difference between the two models of the Udhrî poem.

In addition, the study argues that classical Arab writers such as Ibn Dawood Al-Asfahani in Al-Zahra and Ibn Hazm Al-Andalusi in Collar of the Dove amongst others referred to Plato's theories in their prosaic writing. It further assumes that Udhrî poets have drawn on the Platonic theories of the chivalric love and the androgyny of the primeval man whose back and sides formed a circle divided into two intersecting semicircles. Each half of the circle yearns for consolidation and reconciliation with the other half. Conceptual convergences and divergences between the Udhrî love and Platonic love remain the central focus of this study.

\section{Origin of the Arab Udhrî Ghazal}

This paper explores the Arab Udhrî ghazal beginning in the pre-Islamic era and flourishing during the Umayyad age; and it introduces Antara Al-Absi as an exemplary poet of the Udhrî ghazal. The fame Al-Absi gained was for the combatant chivalry as well as spiritual chivalry he, respectively, demonstrated in the battlefield and life. The constituents of Al-Absi's chivalry include chastity, abstinence from trivialities, and commitment to high morals. War chivalry can accordingly be distinguished from the moral chivalry which promotes ideal behaviors, divine love and chastity (Al-Batal, 1984, p. 178). Al-Absi fell in chaste love with his cousin Abla bint Malik Ibn Qrad. The combination he managed to maintain between his passions as a chivalric lover astonishingly influenced the European and World literatures (Tawfiq, 2015, p. 2).

Dhaif (1977) considers Al-Absi "the father of Arab chivalry in its high morals which drew the attention of the crusaders and set an example for their chivalry in its emphasis on chaste love" (371). Dhaif refers to Al-Absi as the forefather of the Udhrî love because: "for the length of his life, he as a repelled lover has written love poems for her. The poems he wrote convey a depressed and melancholic tone. He is recognized as the founder of both chivalric and Udhrî love poetry in Arabic" (371). 


\section{Reasons for the Rise of Udhrî Ghazal}

Literary phenomena are unquestionably products of environmental factors. The environment of the pre-Islamic age in which the Udhrî ghazal emerged needs to be thoroughly studied. In a study, Abu Sweilim (1987) goes beyond reviewing the successive biographies of Antara Al-Absi and, instead, focuses on his Mu'allaqât (a group of seven long Arabic poems). He argues that "Abla remains present in his conscious. Her image controls and reforms the various images his Mu'allaqât include" (24). He finds that Al-Absi shows sublime love emotions and perseverance in his resistance to passions and desires. Deterred by his chastity, Al-Absi could have taken her by force like any other shielded knight. He disdained immoral vices and abided by the codes of dignity, chivalry and Udhrî love. His Mu'allaqât implicitly express his rejection of both slavery and captivity in the pre-Islamic era (Sweilim, 25). The Udhrî ghazal exemplified by the poetry of Al-Absi has, accordingly, existed since the pre-Islamic age, prior to Islam and the Umayyad Caliphate.

\subsection{Role of Environment in the Rise of Udhrî Ghazal}

Some scholars etymologically associate the concept of Udhrî love with Udhra tribe in Wadi Al Qura located to the North of Hijaz (Dhaif, 1977, p. 359). However, others identify with Taha Hussein's belief that they were referred to as Udhrî poets for their consideration of the Udhrî ghazal as an autonomous subgenre but not for their descent from Udhra. A third group of scholars believes that it has been called Udhrî love for its renunciation of erotic love (Hussein, 1976, p. 174).

The seeds of this poetic movement are found to be in Al Absi's Mu'allaqât. Al-Absi lived in a society, where slaves and half-breed children were denied freedoms. His father set him free; and his chivalric capabilities helped him conquer other warriors in the battle field. Yet, he could not marry his cousin Abla as suggested by his saying:

$$
\begin{aligned}
& \text { inn taghaddafi duni alqunae f'inny } \\
& \text { tb bi'akhdh alfaris almustalyim } \\
& \text { 'aththani ely bima ealimt f'inny } \\
& \text { samh mukhalaqati 'iidha } 1 \mathrm{~m} \text { auzlm } \\
& \text { fa'iidha zalamt fa'inn zilmi basil } \\
& \text { murr mdhaqth katem alelqm } \\
& \text { walaqad sharit min almudamat baedama } \\
& \text { rakd alhawajir bialshshawf almaelam }
\end{aligned}
$$

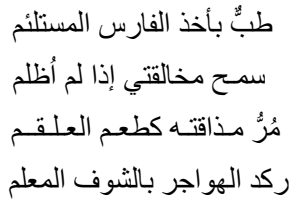

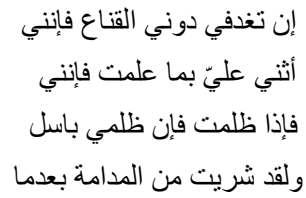

The indifference and disregard Abla meets him with evoke his dignity as well as his poetic talent which discharge his unrequited and underestimated passions and feelings. In his Mu'allaqât, Al-Absi extensively takes a pride in his chivalric values of courage, vigor, chastity and high morals. He, in turn, responds to the indifference and disrespect of his beloved by asking her to recognize and commend his chivalry. The suffering and pain she causes to him are discharged in his representation of wine as "an escape from the painful reality he lives. He drinks wine on public during the stillness of the noon. He does not drink wine in pursuit of pleasure; rather, he desperately consumes it in search for forgetfulness. His spiritual power along with his chivalry provides him with patience to sustain injustices" (Sweilim, 26).

In addition, dominant tribal systems enforce laws and customs to regulate intra-tribal relations and categorize people into unchallengeable hierarchical ranks. The social class of slaves and half-breeds to which Al-Absi belongs are dispossessed of autonomy and free will. The unique chivalric and moral attributes characterizing Al-Absi never achieve social mobility for him because the exclusive political discourse, under which he was brought up, nurtures a sociopolitical system discriminating and belittling people of lower classes and races. Poverty and despair have arisen as grave outcomes of the systems defining the pre-Islamic age during which slaves were not expected to fall in love or marry women of higher classes and races. Realizing that Al-Absi's mother was a slave, Abla disparages and views him not as a knight but still as a slave.

The re-emergence of Udhrî love during the Umayyad Age is associated with similar political and environmental conditions to those characterizing the pre-Islamic age, like transformation from the hegemony of the individual to the tribe, and from the hegemony of the tribe to the state. The political system by which the tribe ruled its members was replaced by the Umayyad Caliphate. In addition, an environmental change has taken place considering the different geographical areas to which the Umayyad state extended. Instead of Al-Hijaz, alshsham (the Levant) was chosen the capital of the Umayyad State; and Iraq became the stronghold of the opposition. Al Hijaz featured a civilized aristocratic community inundated with gold and slaves (Hussein, 188) and a Bedouin community experiencing political as well as economic marginalization and disenfranchisement. Therefore, the latter lived in an isolated environment away from cultural and economic exchanges with traders and singers. The Bedouin environment has managed to maintain its pre-Islamic traditions and customs though Islam has approved some of the traditions related to the modesty 
and chastity of women. The environmental conditions Al-Absi encountered in the pre-Islamic era are reproduced at a narrower level in the Umayyad state as they are not limited to a member of the tribe but to a marginalized geographical area.

Udhrî love has primarily arisen because of the social system. In his investigation of the reemergence of the Udhrî ghazal in the Umayyad age, Hussein (1976) argues that "the poetic forms of erotic ghazal and Udhrî ghazal are products of the social system in the Umayyad age" (188). Hussein's argument, the authors believe, may truly account for the rise of erotic ghazal in Al Hijaz cities where money, gold, slaves and singers were concentrated. The Udhrî ghazal, however, characterized the Bedouin communities of Al-Hijaz which remained isolated from the opulent lifestyle of Al Hijaz cities. Following the Islamic conquests, Bedouin communities were not exposed to intercultural exchanges with other nations, cultures and societies. The isolated environment in which the Bedouins lived made it possible for them to maintain their chastity and virtues.

The Udhrî ghazal was not influenced by Islam either according to Taha Hussein who reveals that "Udhrî poets descended from Bedouin tribes with no significant contributions to the history of Islam. Most tribes adhered to their pre-Islamic inherent heritage" (Shukri, 1959, p. 232). While this study identifies with Hussein's perspective, it refutes the counter argument of Shukri Faisal who considers Islam a major stimulant for the rise and flourish of the Udhrî ghazal in the Bedouin environment of Al Hijaz. The Udhrî ghazal, Shukri assumes, "expresses the perspective of a group of Muslims who preferred safety to adventure and believed in the sinful nature of human beings and in the desires with which the Hell fire is encompassed" (Hills, 2002, p. 27). That claim cannot be assumed to be true on the ground that it raises the following questions: why did not Islam influence people in Mecca and Madina? Why did not it influence the poetry of Omar Bin Abi Rabia' who was born and brought up in Mecca? Why did not it influence the courtly poetry of Abdullah Bin Amro Al-Arji whose lineage comes down from Othman Ibn Afan in Madina? And why did not it influence the poetry of Abdullah Ibn Mohammed Al-Ahwas? The current study assumes that Islam did not cast its shadow on the works of the poets who were born and brought up in the strongholds of Islam and the Umayyad Caliphate.

Historical conditions as well should be taken into account when investigating social formations and phenomena. The language and words, which the members of a particular social class use, do not express an individual perspective but a collective perspective (Al-Nahhas, 1986, Vol. 2, p. 11). Social traditions, customs and norms are determined by what is called the collective consciousness. The formation of a social phenomenon is accordingly framed by spatial and temporal conditions.

\section{Stages of the Udhrî Love}

Five stages through which the Udhrî love passes can be identified. In the first stage, the poet and his beloved, who are usually cousins, accidentally meet for the first time. In reference to Abla in one of his poems, Al-Absi says:

$$
\begin{aligned}
& \text { ealaqtha eardaan wa'aqtal qawmaha } \\
& \text { zuemana llaeimr 'abik lays bimazeim } \\
& \text { walaqad nuzzilat fala tazanni ghyrahu } \\
& \text { minni bimunzilat almuhibb almukarram }
\end{aligned}
$$

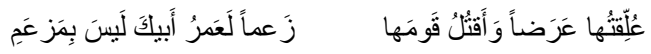

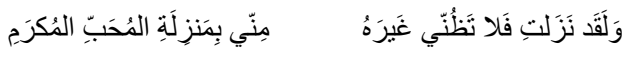

In like manner, Qais Ibn Al Mulawah expresses his passions to his cousin Laila whom he has been in love with since their childhood:

$$
\begin{aligned}
& \text { taeallaqat laylaa wahi ghr saghirat } \\
& \text { walam yabid lil'atrab min thadayha hajm } \\
& \text { sughirin nureaa albahum ya layt 'annana } \\
& \text { 'iilaa alyawm lm nakbur walam tukabbir }
\end{aligned}
$$

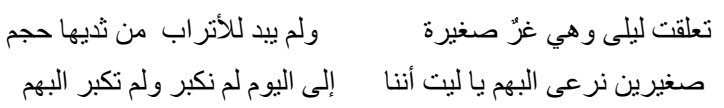

Jamil Bin Mo'amar also accidentally meets Buthayna by a spring where each was watering his sheep. Despite the insults they threw at each other in their first meeting, they fall in love as suggested by Mo'amar's saying:

$$
\begin{aligned}
& \text { wa'awwal ma qad almawaddat baynana } \\
& \text { biwadi bighayd ya bithayn sabab }
\end{aligned}
$$

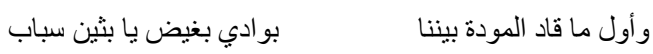

Need for water (Dhaif,1999, p. 98) was often the first motivation for the first meeting followed by a kinship relation (Ibn Mu'amar, pp. $27-28$ ) between the poet and his beloved. Yet, it should be mentioned that the first meeting in an Udhrî love story is similar to that in any other love story. 
In the second stage, the poet composes poems in which he refers to and expresses his love to his beloved. When their love story gets publicly disseminated, the poet has to struggle against the wish of her family; so, he secretly begins to have regular dates with her. The secret dates Buthayna and Jamil used to have and the fear they felt are referred to in the following lines:

fama zilt fi 'iiemal trfk nahuna

'iidha jit hatta kad habbik yuzhir

wa'akhshaa abn eemy ealayka, wa'innama

yakhaf wayattaqi eirdah almutafakkir

ghryb 'iidha ma jit talab hajtin

wahawly aeda'un, wa'ant mshhhar

waqad hddathu anna ailtaqina ealaa hwaan

faklihim min hamalih alghayz mwqr

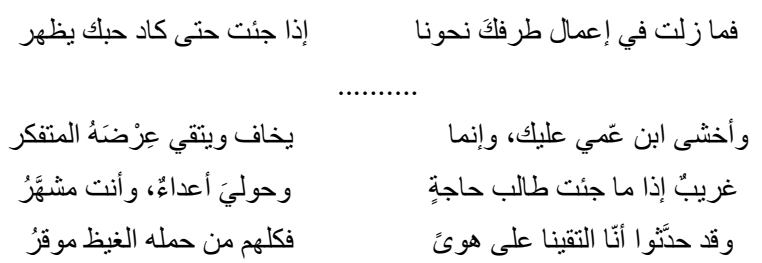

In the third stage, the poet proposes to his beloved, but her father opposes their marriage. Only in two love narratives has the proposal of an Udhrî poet been accepted; yet, both ended in divorce as it will be shown later. The decline of the marriage proposal made by a lovelorn poet pertains to: first, the Arabs used not to marry their daughters to those who publicly court and flatter them (Ibn Qutaiba, p. 90, 104); second, the poet's economic inability to afford the dowry a greedy father demands might result in the decline of his marriage proposal (Ibn Qutaiba, pp. 55 - 59).

In the fourth stage, the poet converses with his beloved following her marriage to another man. The consequences of their conversations range from killing the lover out of jealousy to compelling the wife to damn and curse her lover. The husband may also complain the lover to his father or to the concerned authorities (Ibn Qutaiba, p. 94). In a very uncommon incident, the husband allows his wife to meet her lover like in the story of Orwah Ibn Huzam and his beloved Afra (Ibn Qutaiba, pp. 132 -142). There are still stories in which the poet does not propose to his beloved despite the possibility of getting his proposal accepted.

There are two stories in which the Udhrî poet and his beloved get married. In the first story, Abdullah Ibn Al-Ajlan AlNahdi - an Udhrî pre-Islamic poet descending from the tribe of Fudha'ah- loved a young woman named Hind from his own tribe of Nahd. Their inability to have a child after several years of their marriage resulted in their divorce upon the request of his father (Al-Asfahani, vol. 9, pp. 212 - 253). In the second story, Qais Ibn Thuraih Al-Laithi (68 H) married Luban Bint Al-Habab Al-Ka'abi Al-Khuza'i whom he had been in love with. Because she remained childless, he unwillingly divorced her. It should be mentioned that the first story occurred in the pre-Islamic age, whereas the second in the Umayyad Age.

In the fifth stage, one of the lovers dies. Whatever the scenario, death in Udhrî love narratives is fantasia-like. The first to die is usually the poet who is purposelessly roaming deserts, desperately living with beasts and constantly suffering the pain of unrequited love and breakup with a beloved departing somewhere else with a husband. In the following lines, Qais Ibn A1 Mulawah reflects upon the desperate state of lovelorn people whom he vainly medicates with fire:

$$
\begin{gathered}
\text { daeuni bighami wanhaduu fi kla't } \\
\text { mmin alllah qad 'ayqanat 'ann last biaqiana } \\
\text { fama bal qalbi hddh alshshawq walhuaa } \\
\text { wa'anduj hru albayn minni fawaadi } \\
\text { ala layt eayni qad ra'at min rakm } \\
\text { le'lly 'aslu saeat man hiaamia } \\
\text { wahihat 'ann 'aslu min alhuzn walhuaa } \\
\text { wahadha qamisi min jwaa albayn balia } \\
\text { faqult nasim alrrih adda tahiyati } \\
\text { 'iilayha wama qad hll bi w dhania } \\
\text { fa'ashkarh 'inni 'iilaa dhak shayiq } \\
\text { fia layt shaeri hal yakun talaqia }
\end{gathered}
$$




$$
\begin{aligned}
& \text { دعوني بغمي و انهذو ا في كلاءةٍ }
\end{aligned}
$$

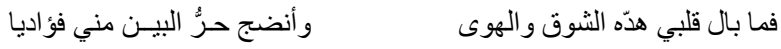

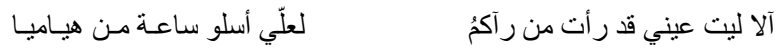

$$
\begin{aligned}
& \text { و هيهات أن أسلو من الحزن و الهوى وهذا قميصي من جوى البين باليا }
\end{aligned}
$$

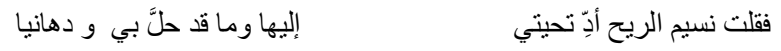

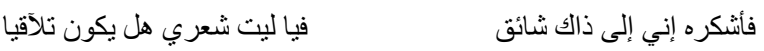

The excessive despair the lover feels ultimately results in his death. When the news of the lover's death is broken to the beloved, she unexpectedly wails and mourns him with other women in the tribe. The whole tribe will also express undue sorrow and regret for his death. Wailing and frequent visits to the grave become a habit for the beloved till she dies (Al-Asfahani, vol. 2, p. 82) and is buried next to him in the same grave (Dhaif, 1999, p. 89). In the love story of Orwah Ibn Huzam and Afra, it is reported that the intertwined trunks of the two trees growing on their grave stands as a symbol of the immortality of their love(Dhaif, 1999, p. 97).

\section{Modernists' Interpretive Points of View on the Udhrî Love}

Modernists widely believe that Udhrî poets choose or love one woman for whom they faithfully devote their life. The lover's obsession with his beloved increases, but the hopes attached to her cease. She becomes the example he likes to bind his life with (Dhaif, 1999, p. 100). The lover's feelings of despair and deprivation drive him neither to forget his old beloved nor to pursue happiness with a new one on the account that he views her as a model (Khlaif, 1998, p. 59).

Despite scholars' overemphasis on the mutual faithfulness between lovers, suspicion and distrust may arise between them. In an endeavor to extinguish suspicion and conciliate confidence, lovers usually test the fidelity of one another. Azza, for instance, tests the fidelity of Kathir twice. At the first time, she veils her face and begins strutting and waddling to which he responds by saying:

ma wasal ezzat 'illa wasal ghaniatan

fi wasal ghaniat min wasaliha khalf

$$
\text { ما وصل عزَّة إلا وصل غانية في وصل غانية من وصلها خلف }
$$

When he later asks whether she agrees to be his mistress, she unveils her face and damns him as a "disloyal lecherous person" (Dhaif, 1999, p. 100). At the second time, Buthaynah (Jamil's beloved) is persuaded of dating Kathir who starts courting her (Dhaif, 1999, p. 101) while Azza is secretly observing and listening to their conversation. Buthaynah as well pretends to be in love with Lahjana Al-Hilali and Tawba Ibn Al-Himyar. Jamil responds to that pretence by admonishingly saying:

bayna habbal dhat eqd libithint

'atyh lha bied alghwat fhlha

faeadna ka'ana $1 m$ yakun baynana hawaa

wasar aldhy hall alhibal hawaa laha

waqaluu naraha ya jamil tabaddalt

waghayriha alwashy faqlt lelh

$$
\begin{aligned}
& \text { بَيْنا حبال ذات عقدٍ لبتينـة }
\end{aligned}
$$

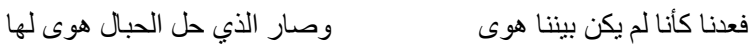

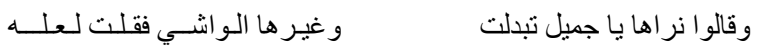

Unlike Jamil and Buthaynah who rekindle their love after being apart, love and compassion in other stories may turn into aversion and antipathy. In the love story of Al Abbas Ibn Al-Ahnaf and Fawz, the former feels extremely depressed during the period Fawz spends in Mecca performing Hajj. Upon her return, he joyfully says:

$$
\begin{aligned}
& \text { ala qid qdimt fwuz } \\
& \text { fqrt eyn 'aabs } \\
& \text { lamyn basharny albushra } \\
& \text { ela aleynyn walras }
\end{aligned}
$$

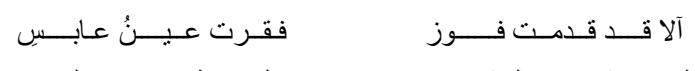

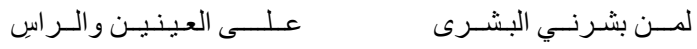

Fawz tells the messenger he sends to her that she is in love with a soldier. Al-Ahnaf meets her infidelity with rebuke and contempt as evidenced in his statement that:

ya fawz lm 'uhjirkum lymalalt

minni wala limaqalat washin Hasid

lakunni jarbatukum fawajadatkum

la tasbirun ealaa taeam wahid 


\begin{tabular}{|c|c|}
\hline مني و لا لمقالة و اشٍ حاسد & يا فوز لم أهجركم لملالةٍ \\
\hline لا تصبرون على طعام واحد & لكنني جربتكم فوجدتكم \\
\hline
\end{tabular}

Another modernist belief concerning the Arabs' habit of not marrying their daughters to those who court and flatter them should be critically questioned. Dhaif (1977) explains that Udhrî love stories are interestingly simple and naïve. Their narrators creatively relate the stories of lovesick protagonists and introduce readers to unpracticed and unfounded customs and traditions. They, for instance, claim that the Arabs used not to marry their daughters to those courting them in poetry for the shame such a marriage may cause for the family and tribe. However, it is a tradition that has never been practiced in either the pre-Islamic or Islamic eras (360). Such an unpracticed belief can be perceived as an irony based on the assumption that, contrary to the jealousy and honor of the Arabs, they used to contest for marrying the courted and flattered women. The news disseminated about Qais Ibn Al-Mulawah's unrequited love to Laila, for instance, encourages many young suitors to propose for her. The proposal a wealthy young man from the tribe of Thaqif in the city of Taif makes is accepted (Dhaif, 1999, p. 38). The situational irony in which suitors contest for marrying the woman whom a lovesick poet courts might be a plot narrators invent to create suspense and coherence. It is a naïve fabricated plot which one can hardly believe.

\section{Counteracting the Modernists' Points of View}

The Udhrî lover's abstinence from marriage in the absence of hindrances refutes the claims about a possible correlation between the socio-cultural system and the decline of marriage proposals made by Udhrî poets. Three stories instantiate such an abstinence. First, Abbas Ibn Al-Ahnaf restricted the motifs of his poetry to ghazal; he never praised or satirized anybody, a characteristic Al Jahidh liked about his poetry. In most of his ghazal poems, he expresses the pain his love to Fawz has caused to him. He patiently waits for her to return from Hajj in Mecca. When he realizes that she abandoned him for a soldier (Dhaif, 1999, pp. 132 - 142), he never proposes to marry her.

Second, Abdulrahman Ibn Abi Ammar from the tribe of Jasham falls in love with Salamah Al-Qis. He was alternatively known with the epithet of Al Qis, an Arabic word meaning hermit, for his excessive devotion to God and performance of prayers. His beloved came to be known with that epithet rather than with her family name. Abdulrahman Al-Qis doted upon her and was about to give up worship and devote his life for her. For no given reason, he never proposed to her, relinquished courtly poetry and subsequently devoted himself to worship. Dhaif (1990) introduces Al Qis as a "hermit known for his piety, worship and asceticism... he was a reciter of the Holy Quran and a narrator of the prophet's Hadith... In his perception of love, he detaches it from pleasure, joy and mirth. His virtuous love is immersed in deprivation, pain, hardship and misery. Its ecstasy as well as pain are unmatched" (122 - 123). The question one can raise is why he did not marry her to avoid such pains though nothing hindered their marriage.

Third, Al-Harith Ibn Khalid Al-Qurashi, who courted A'esha Bint Talha, restricted his poetry to the motif of ghazal but not satire or eulogy. When her husband Mus'ab Ibn Al Zubair was murdered, he was asked "why do not you marry her now?" In his comment, he disclosed "I do not want the people of Quraish to suspect that I praised and flattered her for ill intentions" (Dhaif, 1999, p. 22). That disclosure suggests that nothing hindered their marriage but his concern about what people thought of him. He further seems to confuse the concept of chastity as he does not know whether proposing to the widow whom he had courted and praised is chaster than being in love with a married woman.

The study further builds on marriage failure by virtue of chance or fate to refute the modernists' claims. Few Udhrî poets were fortunate enough to be bound in marriage with their beloveds though it did not last long. Two unsuccessful marriages amongst Udhrî poets have been reported, namely the marriage of Abdullah Ibn Ajlan Al-Jahli to Hind and the marriage of Qais Ibn Al-Thurayh to Lubna. The current study assumes that it is fate or chance that is going to disrupt their marriage because it is by a mere accident that the two beloveds remain childless and that the two poets were born to wealthy authoritative fathers, who compel them to divorce their childless wives for fear of kalalah (dying without having a parent or child to be a heir) (Khlaif, 1998, p. 31). The study also assumes that narrators might have invented the plots of these unsuccessful marriages to create suspense, especially that the plots in both stories structurally develop as follows: admiration and love, pain of deprivation, marriage, sterility of the wife and divorce.

\section{Islam and the Udhrî Love}

The factors leading to the rise of Udhrî love are still bewildering critics and scholars. Most scholars believe that "Islam with its potentials to purify souls and redeem sins has unquestionably given rise to the Udhrî love" (Dhaif, 1977, p. 359). Its teachings and instructions civilized Bedouin communities and were honorably protective of women and their dignity (Dhaif, 1999, pp. 25 - 26). Islam, for Dhaif, constitutes a major factor for the rise of the Udhrî love; he insists that the Udhrî poets act in concert with the Islamic constants celebrating chastity and purity.

Proceeding from scholars' overemphasis on the correlation between Islam and the Udhrî love, the various stages of that love need to be examined to determine the extent of their compatibility or incompatibility with Islam. We have already mentioned that lovers in the first stage accidentally meet and live together either in a neighboring house or in the same house when the father of either lover, usually cousins, dies. The various circumstances surrounding their first meeting correspond with Islam and other heavenly religions according to many scholars. The second stage in which the lover courts and flatters his beloved is falsely viewed as a spiritual virtuous ghazal lacking sensory images. Yet, a close examination of Udhrî ghazal unveils many sensory images like in the following lines quoted from a poem by Jamil Buthayna: 
wamali la 'abki wafi al'ayk nayih

waqad faraqtni shakhtat alkushh walkhasr

dhakarat maqami laylat alban qabdaan

ealaa kff hura' almadamie kalbadr

tajud ealayna bialhadith wtartan

tajud ealayna bialrradab min alththaghar

laqulat dharuni saeatan wabithinatan

ealaa ghaflat mmin alwashyn thumm

muflajat al'anyab, law 'ann riqaha

yadawaa almawtaa laqamuu bih min alqabr

qanatan min almrran ma fawq huqquha

wama tahtah minha nqaan yatahil

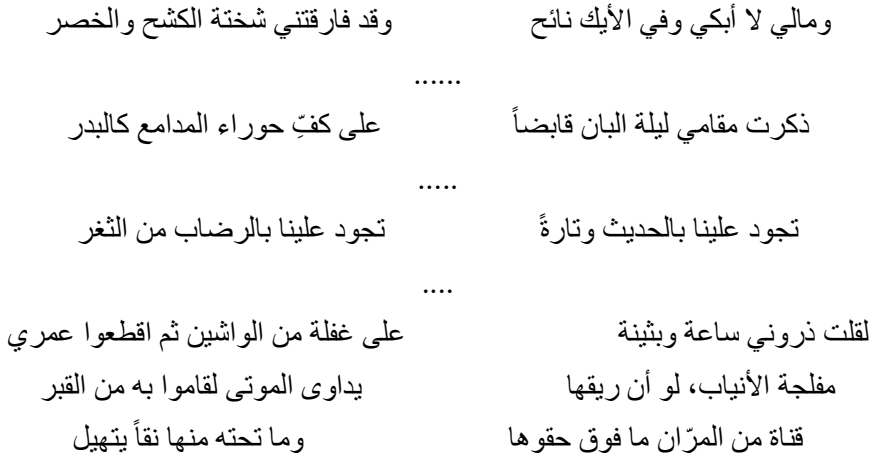

In this poem, Jamil elaborates on the thinness of her waist, taste of saliva in her mouth and beauty of her teeth. Her saliva, Jamil says, tastes so delicious that it may give life to the dead. Her stature is as straight as a spear; and her plump thighs move as gently as a sand dune. These images signify the aesthetics of sensory description and ecstasy of sight in the Arabic romance of Udhrî ghazal.

The ratio of sensory images to spiritual images in the Udhrî ghazal goes beyond the scope of this paper which explores the extent of its compatibility with the Islamic constants regulating the relationship between men and women. Considering the prophetic Hadith in which the messenger of Islam Mohammed, peace be upon him, said "the eye may commit adultery", kissing and caressing are unquestionably forms of adultery. This Islamic constant can be extended to Christianity and other religions. Jesus Christ in his wills, for instance, said "whoever lustfully looks at a woman is deemed an adulterer in heart".

Udhrî lovers were identified by the names of their mistresses such as Qais Lubna, Qais Laila and Jamil Buthayna. AlAndalusi (1977) reveals that "a woman in the Bedouin culture used not to trust or believe a lover till he publicly courted and flattered her" (42). The fame and reputability women pursue do not correspond with the Islamic constants confining them to domesticity and commanding them to be modest and chaste.

The Udhrî motif of khalwa, i.e. assignation, constitutes another incompatibility with Islam. The act of being alone with the beloved goes against the prophet's Hadith in which he says "whenever a man is alone with a woman, Satan will be their third companion". When Buthayna realizes that Jamil was in love with her, she vows not to veil before him and to steal upon him in his solitude. Jamil also used to visit her when nobody was around and to stay up late at night with her till the approach of dawn. At day, they divulge the secrets of their assignations to others in pursuit of fame. The apathy Buthayna's father and brother manifest when finding her alone with Jamil in a deserted place at night further contradicts the chivalric jealousy of Arabs. Instead of getting angry and jealous, her father orders his son not to "stop Jamil from dating her anymore". The instruction the father gives suggests his belief in the chaste love relation between Jamil and Buthayna despite its incongruence with the Arab traditions and Islamic teachings.

As Islam forbids wives from receiving a kinsman without getting the husband's permission, they cannot welcome male guests in the absence of husbands. In the love story of Jamil and Buthayna, "the latter loses interest neither in Jamil who still flirts with her nor in his courting poetry in spite of her marriage" (Dhaif, 1999, p. 55). In the early morning of one day, Buthayna is found to be sleeping with Jamil by the housemaid who immediately breaks the news to Buthayna's husband, father and brother. In another story, Orwah Ibn Huzam steals into Afra's house of marriage. When the husband accidentally catches sight of his wife with her lover, he resignedly says to him, "I wish you would not come back here. He leaves them alone to converse. Having completed their private conversation, Orwah tells her husband how lovesick he is! The husband, who gets sympathized, assures him that he can constantly meet her".

It is not a question of whether such stories are real or invented; and whether the capital punishment for committing adultery in Islam should be executed. This paper, however, questions the concept of chastity in the Arab and Islamic 
culture and the impact of Islam on the Udhrî love and ghazal (Dhaif, 1999, p. 23). Dhaif considers the Udhrî love as a form of Sufi love; or it has prepared for the emergence of the Sufi love. He believes "it is entirely mystical in tone, the subject matter and theme. It is not a hyperbole to conclude that the Udhrî love has initiated a creative revolution in the Sufi poetry" (Al-Adhim, 2002, pp. 65 - 68). Some scholars advocate Dhaif's perspective of the Udhrî love from which the Sufi poetry is believed to have been evolved (Dhaif, 1999, p. 23). Specialists in the Sufi poetry believe that AlHassan Al-Basri (110 AH) and Rabia' Al-Adawyah are the forefather and foremother of the Sufi poetry. Yet, no evidence has been found to correlate Sufism with the Udhrî love (Hilal, 1976, p. 180). Other scholars, nonetheless, view the Udhrî love as a form of challenge to and protest against the Umayyad state (Hilmi, 1985, pp. 140 - 142). The behavioral transcendence the Udhrî love engenders contrarily constitutes the seed from which the Sufi love has grown and evolved as it is evidenced in the stories the Persian Sufis relate (Al-Batal, 1984, pp. 180 - 181).

\section{Udhrî Love and Platonic Love}

The convergences and divergences between the Udhrî love and Platonic love are outlined in this section of the study. Plato's theory of the twin soul in the Symposium has its echoes in the discourse of the Udhrî love. The primeval people were believed to be androgynous creatures with a round body and elements of both femaleness and maleness. Owing to their transgression and disobedience to gods' commands, the king of gods Zeus divided them into two halves and put each half in a person. Each has been loving and looking for its other half or twin soul since then (Al-Batal, 1984, pp. 185 - 186). Love and marriage accordingly help people reclaim their missing part and restore their androgynous nature in an attempt to weld individual creatures into a collective creature.

The shadows of this theory are cast in the writing of classical Arab writers who investigated the concept of the Udhrî love. Al-Asfahani (1985) alludes to the philosophers' claim that God had created round androgynous souls before they were split into a masculine half and a feminine half. When a man accidentally meets the woman, who shares the other half of their androgynous soul, they will fall in love (53 - 54). In contrast, Al-Andalusi (1977) mythicizes the notion of the androgynous creation despite his emphasis on the nostalgia seizing souls to transcend their division and restore their primeval nature. He defines androgyny as a form of communication between the primeval elements of the divided soul rather than the round androgynous soul Al-Asfahani borrowed from the Greek philosophers. Souls are divided based on their potentials and homogeneity in the upper world. Communication and separation accounts for the harmony or disharmony between creatures. Each creature is looking for its counterpart as each proverb needs its equivalence. Homogeneity, in his perspective, has subtle visible effects upon creatures (6).

Those falsifying the roundedness and androgyny of the primeval creatures alternately advocate the common origin theory (fission or scission) and souls' nostalgia to their halved mates. They, in advocacy of that theory, cite the Hadith reported by Immam al-Bukhaaree in his Saheeh that 3Aa'ishah said "I heard the Prophet saying: Souls are like conscripted soldiers; those whom they recognize, they get along with, and those whom they do not recognize, they will not get along with" (Ibn Mandhour, 2011, entry “Jund”). Al-Andalusi goes further to cite the Quranic verse in which Allah says "it is He Who created you from a single person, and made his mate of like nature, in order that he might dwell with her (in love)". Al-Andalusi (1977) persists that common origin rather than physical beauty accounts for love (6). The philosophy signified by the theory of common origin concerns the story of the lovers' creation and the end to which they were created. This concept of love is frequently adopted by such Udhrî poets as Jamil Ibn Mo'amar who, in one poem, says:

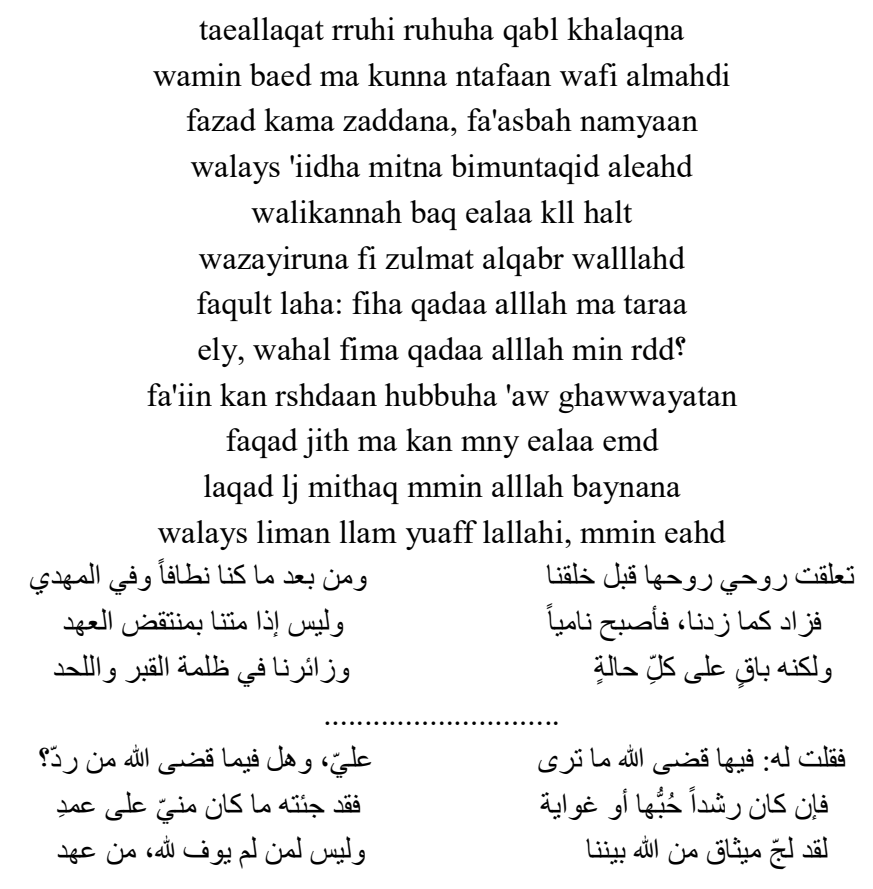

He expresses a similar perception in another poem in which he says: 
'aeudh bik allhumm 'ann tashhat alnnwa

bibathnat fi 'adnaa hayati wala alhashr

wajawar 'iidha mutt bayni wabaynaha

fia hubdhana muti 'iidha jawart qabri

$$
\text { و أعوذ بك اللهُمَّ أن تشحط النّوى }
$$

He maintains that his soul will pursue hers among the tombs of the dead as stated in the following line:

$$
\begin{aligned}
& \text { yahwaku, ma esht alfwadu, fa'inn 'amut } \\
& \text { yattabie sidday saddak bayn alaqbr }
\end{aligned}
$$

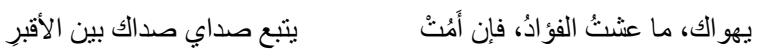

The lines quoted above connote that love had welded lovers' souls together before their bodies were created. As they are transforming from a sperm into human beings, their love constantly grows. Even death does not have the power to bring their love to an end. Love joins them in their tombs and the afterlife as it never dies.

The autonomy of love as perceived by the Udhrî poets stems from the belief that it is not a property of either lover. It communicates with and visits both in the darkness of their graves. Lovers do not possess each other either; yet, they have an unbridled desire to be bound in love or marriage.

The most accurate account of Platonic love is that of Georg Simmel in his statement that "the Greek Eros is a wish to possess ...; to have in the beloved a vessel for ideal instruction and morally elevating cultivation. Therefore, for him love can be an intermediate state between not-having and having" (D'Arcy, 2007, p. 245). The state of having and not having is the frame within which the Udhrî love emerges and thrives whether among lovers in the pre-Islamic age, Islamic age or Umayyad age. A previous section of the current study described a similar state in the course of its overview of the various stages of the Udhrî love. Socioeconomic conditions sometimes result in the decline of the marriage proposal a suitor makes. Parents, at other times, may not marry their daughter to a man praising and courting her in his poetry. Dhaif (1999) disproves that reasoning which he considers fictitious. (90) Still, the poet may willingly desist from marriage like in the stories of Ibn Abu Ammar Al-Nasik and Salma, and Al-Harith Ibn Khalid Al-Qurashi and A'esha Bint Talha. Even the lovers, who luckily get married, create an excuse for divorce. Lovers do this to keep the fire of love kindling and burning in their hearts and restore the state of having and not having. Love, in this sense, is perceived as a third party neither lover possesses. It serves as a bond between lovers upon whom it exercises its autonomy and authority. That love emanates from a divine power in the perception of Udhrî poets makes it irresistible and uncontrollable.

This conception of the Udhrî ghazal explains the overwhelming feeling of non-erotic love which distinguishes it from erotic love. Lovers have a strong desire to develop and maintain their partnership in life and to melt in each other in the afterlife, where they become one androgynous being (Wadghiri, 2013). Unity between lovers is seemingly fulfilled at the soul level in the Udhrî ghazal. This suggests that the physical unity of lovers through marriage either was not possible or signified the decay and corruption of love in the deconstructed plots of Udhrî narratives. Accordingly, love in Udhrî narratives is based on communication and lack of communication, having and not-having.

With respect to the motif of craziness characterizing the narratives of Udhrî poetry, it made the title of such Udhrî stories as Laila's Crazy Lover and Lubna's Crazy Lover. Craziness, therefore, replaced the poet's name and was supplemented to the beloved's. Laila's crazy lover, for instance, refers to Qais Ibn Al-Mulawah and Lubna's crazy lover for Qais Ibn Al-Thuraih. In Plato's theorization, craziness is conceived as a stage of love. Al-Asfahani (1985) indicates that heart generates love expressed in the forms of excessive care, perseverance, anxiety and ecstasy which, respectively, grow into melancholy, irrationality, desperation and craziness (56). Having reached the state of craziness, the lover may kill himself or die of grief or joy when he sees his beloved. The motif of craziness, for some scholars, might have been implied by Plato's insightful statement that "I do not know what love is. Yet, I think it is divine craziness that is neither reputable nor disreputable" (Al-Asfahani, 1985, p. 56). Hippocrates likewise states that love begins in the heart and radiates out into the other organs; it induces tremor of limbs, paleness of skin, importunity in speech and weakness in argument. The lover therefore, experiences a defect in the body, mind or soul (Al-Alawi, 2013). Several Udhrî love stories typify the psychological and mental disorders lovelorn people manifest (Al-Alawi, 2013). The Udhrî love evokes both an internal conflict with self and an external conflict with the social environment. The outcome of such conflicts is either the lover's death or madness (Dhaif, 1999, p. 30).

The Udhrî love as well converges with Plato's theory of the chivalric love which celebrates honor, fulfillment of covenants and reciprocity of love. Uranus classifies love into chivalric and non-chivalric. The chivalric love Uranus appreciates springs from Aphrodite of heavens, whereas the non-chivalric love he depreciates originates from Aphrodite of the earth. The emotions invoking both types account for their difference. In heavenly love, a lover binds himself with an intelligent and chaste partner to whom he remains faithful and concerned about her reputation in observation of the covenant signed (Al-Shahawi, 2016). The love story of Jamil Ibn Mo'amar epitomizes that model as he, in one poem, refers to the contract made with his beloved, like when he says: 
laqad ljj mithaq mmin alllah baynana

walays liman llam yuaff lillah min juhd

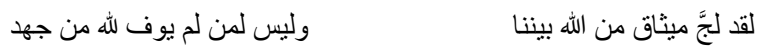

The Greek and Udhrî chivalries considered in this study do not pertain to combat or duel but to high morals, chastity, fortitude and patience. Moral chivalry cultivates the noblest passion of love and the noblest behavioral code of chastity (Wadghiri, 2013) as suggested by Jamil Ibn Mo'amar in his saying:

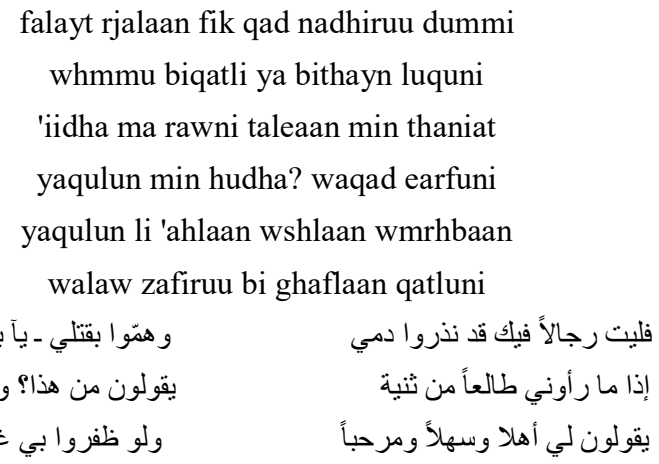

The speaker in that poem looks down on the immoral acts characterizing his foil and contrastively abstains from hypocrisy, mendacity and obscenity as expressed in his saying "they are asking who that man is though they recognize me" (Al-Batal, 1984, p. 178).

Moral chivalry arises from deprivation and hopes mixed with despair. Islam might not have contributed to its rise because pre-Islamic poets such as Al Absi and other lovelorn poets acted in accordance with its virtues. The moral chivalry represented in Al-Absi's poetry, Abu Sweilim (1987) believes, has the potentials to purify hearts and souls from all sins and turpitudes, relieve pain and grief and nurture chaste love (25). In like manner, Dhaif (1977) associates the pre-Islamic chivalry with the virtues of high morals, generosity and prowess which poets celebrated in their poems and were committed to in their lives (371). The pre-Islamic chivalry accordingly converges with the Platonic chivalry as both seek to free people from vices and atrocities and enhance moral conduct.

\section{Conclusion}

The study critically reviews the historical and conceptual development of the Udhrî love and questions the modernists and classicists' views pertaining to it in an attempt to unfold the major factors leading to its emergence. The theories of love proposed in Plato's Symposium, the study argues, have laid the philosophical foundation and premises of the Udhrî ghazal which emerged since the pre-Islamic era and continued to the Islamic and Umayyad ages. The study refutes the assumptions modernists made about the effect of Islam on the Udhrî ghazal by highlighting many discrepancies between them. Despite the existence of studies detaching the Udhrî ghazal from the Platonic love on the account that each has its own characteristics and approaches, the study emphasizes that the Udhrî ghazal converges with the Platonic concept of love. The difference in the topics addressed, the study concludes, does not necessarily mean a difference in style and method. Proceeding from that conclusion, the Udhrî ghazal can be approximated with Plato's theories on love.

\section{References}

Abu Sweilim, A. (1987). Studies in the Jahili Literature, Al-Jeel Publishing, Beirut.

Al-Absi, A. (2010). Diwan, Mohammed S. Al-Mawlawi (ed.), Islamic Office, Damascus.

Al-Adhim, S. J. (2002), In Love and the Udhrî Love, Al-Mada Dar for Culture and Publishing, Damascus.

Al-Alawi, M. H. (2013). Echoes of Plato's Symposium in the Classical Discourse of Arab Prose, Sadana Cultural Journal, Retrieved from http://www.saddana.net/?p=12227

Al-Andalusi, M. (1977). Collar of the Dove, H. K. Al-Seirafi (Ed.), Al-Istiqama Publishing House, Cairo.

Al-Asfahani, M. (1985). Al-Zahra, I. Al-Samira'i. (Ed.), Al-Manar Bookshop, Zarqa (Jordan).

Al-Asfahani, M. (2011). Al-Aghani, A. Mhana and S. Jabir. (Eds.), Dar Al-Fikr for Publishing and Distribution, Beirut, 1999.

Al-Batal, A. (1984). The Udhrî Ghazal and Reality Disorder, Fussul: Journal of Literary Criticism, 4(2).

Al-Mulawah, Q. (1999). Diwan, A. B. Al-Wali (Ed.), Scientific Books Dar, Beirut.

Al-Nahhas, A. (1986). Guide to the Famous Poems Known as Muw'alaqat, Scientific Books Dar, Beiruit, 2.

Al-Shahawi, S. (2016). Ambiguity of Concepts across Civilizations: Udhrî Love as a Model, Arrafid, UAE, Retrieved from: http://www.arrafid.ae/arrafid/p16_6-2011.html

D’Arcy, M. C. (2007). The Mind and Heart of Love: Lion and Unicorn, A Study in Eros and Agape, Kessinger Publishing.

Dhaif, S. (1977). History of the Arab Literature, Al-Ma'arif Dar, Cairo. 
Dhaif, S. (1999). The Arab Conception of the Udhrî Love, Lebanon Egyptian Dar, Cairo.

Hilal, M. G. (19760). The Emotional Life between the Udhrî Love and Sufi Love, Al-Nahda Dar, Cairo.

Hills, J., Julian G., and David P. (2002). Understanding Social Exclusion, Oxford University Press.

Hilmi, M. (1985). Ibn Al-Faridh and the Divine Love, Al-Ma'arif Dar, Cairo.

Hussein, T. (1976). Al-A'arbi'aa Talk, Al-Ma'arif Dar, Cairo.

Ibn Mandhour, M. (2011). Lisaan Al-Arab, entry “Jund”, Dar Al-Ma'arif.

Ibn Mu'amar, J. (1982). Diwan, Beirut Dar for Publishing and Distribution, Beirut.

Ibn Qutaiba, A. (1985). Poetry and the Poets, M. Qmaiha (Ed.), Scientific Books Dar, Beirut.

Khlaif, Y. (1995). In the Umayyad Poetry: a Study of the Environment, Gharib Bookshop, Cairo.

Khlaif, Y. (1998). The Arab Conception of the Ideal Love, Qibaa' Dar for Publishing and Distribution, Cairo.

Shukri, F. (1959). Development of Ghazal between the Pre-Islamic and Islamic Ages, Damascus Mosque Publishing.

Tawfiq, B. (2015). Chivalric Literature between the East and West, Al-Raya Newspaper, Qatar, Retrieved from:

http://www.raya.com/news/pages/b93d6ba1-820e-4f05-8fb9-20781a5394bb

Wadghiri, H. (2013). Theories of Love Based on Plato's Symposium, The Civilized Debate, Retrieved from: http://www.ahewar.org/debat/show.art.asp?aid=340508 